\title{
Reproductive biology of Davilla kunthii A. St-Hil. (Dilleniaceae) in Central Amazonia
}

André Rodrigo Rech ${ }^{1,4}$, Fatima Cristina de Lazari Manente-Balestieri ${ }^{2}$ and Maria Lúcia Absy ${ }^{3}$

Recebido em 4/12/2010. Aceito em 17/05/2011

\begin{abstract}
RESUMO
(Biologia reprodutiva de Davilla kunthii A. St-Hil. (Dilleniaceae) na Amazônia Central). Este trabalho descreve as relações entre visitantes florais e Davilla kunthii A. St.-Hil., bem como características de sua biologia reprodutiva em Itacoatiara (Amazonas). Foram realizados os testes referentes ao estudo do sistema reprodutivo. A guilda de visitantes foi caracterizada quanto à riqueza, abundância, frequência relativa e constância. Os testes para sistema reprodutivo indicaram que $D$. kunthii possui auto-compatibilidade. O mecanismo de polinização configurou-se como generalista com 39 espécies de visitantes florais, provenientes de três diferentes ordens. Abelhas corresponderam ao principal grupo de polinizadores, desta forma, alguns aspectos comportamentais foram descritos. O horário de maior forrageamento ocorreu entre 7 e 10 horas. Algumas espécies apresentaram interações agonísticas e comportamento monopolizador da fonte de alimento. Dado o comportamento e o potencial destrutivo, embora possa ocasionalmente atuar como polinizadores, Curculionidae parecem possuir maior impacto como predadores de sementes.
\end{abstract}

Palavras-chave: abelhas, comportamento do polinizador, liana, polinização

\begin{abstract}
(Reproductive biology of Davilla kunthii A. St-Hil. (Dilleniaceae) in Central Amazonia). This survey aimed at describing the interactions of floral visitors and Davilla kunthii A. St.-Hil. as well as characteristics of its reproductive biology in Itacoatiara, state of Amazonas, Brazil. Tests of the breeding system were performed. The guild of visitors was described according to richness, abundance, relative frequency and constancy. The breeding system tests indicated that $D$. kunthii is self-compatible. The pollination system was characterized as generalist, with 39 visitor species, from three different orders. Bees were the main group of pollinators, thus some behavioural aspects were described. The period of highest foraging activity was between 7 and $10 \mathrm{am}$. Some species presented agonistic and monopolistic behaviour. Given the behaviour and destructive potential, the Curculionidae seem to have a greater impact as seed predators than pollinators.
\end{abstract}

Key words: bee, pollinator behaviour, vine pollination

\section{Introduction}

Considering its geographic area and biological diversity, it is acceptable that the Amazon rainforest harbours many biological and ecological mechanisms still unknown to science. Plant-pollinator interactions are among the processes that characterise the complex dynamics of this ecosystem. More than $90 \%$ of all flowering plants of the tropical lowland rainforest have biotic vector-mediated pollination (Bawa 1990). Among the biotic agents, insects predominate over other animals, as they are abundant and have vision capable of differentiating chromatic patterns and forms and have a large energetic demand due to their high metabolic activity (Ollerton 1999).

Among the insects, bees form the principal group of pollinators due to their diversity and potential generalism (Michener 2000). They permanently demand food harvest in great quantity. Moreover, the potential polytrophism of bees is caused by nutritional dependence upon pollen and nectar throughout life (Corbet et al. 1991; Free 1993). Many bees also have a good system of communication and are capable of specialising on food resources for some periods of time, thereby granting a certain degree of fidelity to them (Ollerton 1999; Ramalho 2004).

\footnotetext{
1 Universidade Estadual de Campinas, Programa de Pós-Graduação em Ecologia, Laboratório de Biossistemática, Campinas, SP, Brazil

2 Universidade Federal da Grande Dourados, Faculdade de Ciências Biológicas e Ambientais, Laboratório de abelhas Nativas, Dourados, MS, Brazil

Instituto Nacional de Pesquisas da Amazônia, Programa de Pós-Graduação em Botânica, Laboratório de Palinologia, Manaus, AM, Brazil

4 Corresponding author: arech2003@yahoo.com.br
} 
Interaction networks of different pollinators and plant species with shared pollen vectors may cause competition either for the food resource, such as that among floral visitors that share the same trophic niche (Ramalho 2004), or, among plants, for pollination agents (Bell 2005; Caruso 2000). Concerning competition for food sources, there may be behavioural and physiological alterations among species: differences in foraging time, varying distribution through resource patches and even agonistic interactions that may lead to food source monopolisation (Roubik 1989; Herrera 1995; 1997; Ramalho et al. 2004).

On the other hand, there is competition for pollination agents when two or more sympatric plant species have a concomitant flowering period and similar floral characteristics (Caruso 1999; 2000). In this case, that competition may occur due to the preferences of the pollinator or inappropriate pollen transfer (Bell et al. 2005). The first case occurs when a more attractive plant draws visitors away from other plants, whose reproductive successive is consequently negatively affected (Waser 1983; Sih \& Baltus 1987; Brown et al. 2002). The inappropriate transfer of pollen occurs when heterospecific pollen is deposited on the stigma of one or more competitors, similarly decreasing seed set (Rathcke 1983; Brown \& Mitchell 2001).

There may also be inter-population variations in the visitor-guilds' structures as well as the manner in which floral rewards are exploited. The causes that govern interpopulation variation of pollinators for a certain plant species, which consequently promote generalised pollination systems, are diverse. These causes may be nested according to the ecophysiological requirements of the pollinator (Ramalho et a.l 1994; 1998; 2004; Herrera 1995; 1997; Hilário et al. 2000; 2001; Kajobe et al. 2007), plant population size (Eckhart 1991; Conner \& Neumeier 1995; Roll et al. 1997), and competition with more sympatric species (Caruso 2000).

Contrary to the discussion of generalisation-specialisation of pollination mechanisms, Armbruster et al. (2002) and Fenster et al. (2004) point out that a plant with an assembly of phylogenetically unrelated floral visitors does not necessarily indicate a generalised system. According to these authors, many visitors can be included in functional groups, which permit the understanding of specialisation as adaptive evolution. Other ways to understand the same phenomenon refer to time of anthesis (Armbruster 1985; Stone et al. 1998), location of pollen deposition (Nilsson 1987; Armbruster et al. 1994), or even homoplasies of floral traits (Schemske 1981; Nilsson 1983; Temeles \& Kress 2003).

Davilla Vand. is one of the most diversified genera within the Dilleniaceae Salisb. and comprises about 30 neotropical species of lianas and erect or climbing shrubs. Its distribution ranges from eastern Mexico to Bolivia, Paraguay and southern Brazil. This genus is represented by commonly occurring species and is indicative of forest borders and environments of high insolation, typical of fragmented landscapes, ecotones, or clearings (Armelin \& Mantovani
2001; Nascimento \& Laurence 2006). The reproductive biology of the genus Davilla is scarcely known. Regarding floral visitors, among reports concerning the genus Davilla, Ducke (1902) reported Halictus Latreille 1804 visiting flowers of $D$. rugosa Poir. For the same species, Kuhlmann \& Kühn (1947) indicated bees and other insects as pollinators. Croat (1978) verified flowers of $D$. nitida (Vahl) Kubitzki being visited by Partamona cupira (Smith 1863). This survey aimed to describe the reproductive biology of Davilla kunthii A. St.Hil, in the municipality of Itacoatiara (Amazonas).

\section{Materials and methods}

This survey was carried out in the municipality of Itacoatiara, in Central Amazonia ( $58^{\circ} 45^{\prime} 41^{\prime \prime} \mathrm{W}$ and $03^{\circ} 02^{\prime} 44^{\prime \prime} \mathrm{S}$ ), on the borders of native forest patches ("terra firme" forest) that form a mosaic inside an area of Brazil nut cultivation (Bertolletia excelsa Humb. \& Bonpl.).

Morphology and floral biology such as flowering rhythm (number of flowers opening per day) and time of odour liberation were assessed in situ in 10 plants. The flowering rhythm was characterised by marking 10 inflorescences (two per plant) and conducting continuous observations from anthesis of the first flower until complete senescence of all flowers of each inflorescence. We monitored 30 flowers from five individuals for pollen availability (anther dehiscence) as well as for stigmatic receptivity, which was assessed by means of the activity of peroxidase, using hydrogen peroxide (10 volumes) dropped directly on the stigma in order to observe bubble formation (Kearns \& Inouye, 1993). Tests of the breeding systems were performed with floral buds prior to anthesis in at least 10 different individuals and always on the base of the inflorescence. The buds were bagged in order to avoid any contact with possible pollinators. Five treatments were performed: spontaneous self-pollination (n: 1.633), manual self-pollination (n: 337), geitonogamy (n: 296), xenogamy (n: 298) and agamospermy (n: 77). For similar fructification frequencies we use a statistical test $\chi^{2}$ (p:0,05). Not all treatments co-occurred in the same individual. With the exception of the self-pollination treatment, all flowers were emasculated between 6:00 and 6:30 a.m. before anther dehiscence. In total, 524 developing fruits were marked (seven inflorescences, one per plant) to evaluate natural pollination (pollen-vector-driven fruit-set) and another 950 (twelve inflorescences, one per plant) were marked and collected after 5 months to verify the presence of Curculionidae larvae.

Field work consisted of direct observation of four sample groups (A, B, C and D) of D. kunthii. Each group was observed during three consecutive days in August 2007. Although it was difficult to determine the number of individuals in each sample group (vine), all were of similar area (about $100 \mathrm{~m}^{2}$ ) and showed similar floral displays. Hence, our total observation time consisted of 12 days (three days per plant group) and 84 hours. The sample groups were 
more than $4 \mathrm{~km}$ away from each other so as to assure no overlapping of bee foraging area (Araujo et al. 2004).

Observations started at 5:00 a.m. and lasted until the sepals closed and the bees' foraging period ended, which was around 12:00. Observations were conducted during one hour intervals. During the first 20 minutes of each hour, floral visitors were quantified. In the remaining 40 minutes, we analysed details of visitor floral behaviour. The structure of the bee guild was characterised by richness, abundance and relative frequency of species. To characterise constancy, we utilised the classification of Bödenheimer (1955): species with a relative frequency $\geq 50 \%$ were considered constant species $(\mathrm{W})$; accessory species $(\mathrm{Y})$ had a relative frequency between 25 and $50 \%$; and rare species $(\mathrm{Z})$ had a relative frequency lower than $25 \%$.

To verify the existence of differences between foraging intensities or foraging times, the abundance of visitors in each hour was considered a dependent variable. The experimental design was organized by way of sub-divided parcels, with the sample groups (A, B, C, D) being considered parcels and the visitation times (hours) being the sub-parcels in a variance analyses. Variance analyses and a regression were calculated using SISVAR software. The species accumulation curve (collector's curve) was based upon the relation of new species per collected individual and it was calculated using ECOSIM software (Gotelli \& Entsminger 2009). A figure describing the interactions between the four plant sample groups and bees was prepared using PAJEK software.

The voucher of D. kunthii was deposited in the herbarium of the Instituto Nacional de Pesquisas da Amazônia (INPA) under number 221995, and the bees were deposited in the Hymenoptera collection of the Universidade de São Paulo (USP), campus of Ribeirão Preto ("Coleção Camargo") and the authors' names follow Camargo \& Pedro (2008).

\section{Results}

The inflorescence of Davilla kunthii (Fig. 1) is terminal or axillary, paniculate $(4-8 \mathrm{~cm}$ long) with bracts $2-4 \mathrm{~mm}$ wide. The flowers opened between 6:00 and 6:30 a.m.; pollen liberation occurred 30 minutes after anthesis, and the sweet floral odour was most intense between 7:00 and 9:00 a.m. The flower is nectarless, plate-like, and actinomorphous. The corolla is yellow and dialypetalous, with four to six elliptical to obovate petals that senesce three to four hours after the beginning of anthesis. The calyx (5-sepals) is asymmetric, three outer sepals smaller than inner acrescent ones, and around 11:00 a.m. the larger sepals close and remain covering the entire developing fruit until maturation. The androecium is dialystaminous with 50-70 stamens, located in concentric verticils. The anthers $(0.25 \mathrm{~mm}$ long $)$ are basifixed and rimose. The ovary is hypogynous, unilocular with two ovules, and the stigma is peltate. Stigmatic receptivity progressively increases until around 9:00 a.m. The fruit is globose with a membranous pericarp.
The flowering pattern was classified as mass annual and asynchronic, with flowers opening non-concomitantly between adjacent sample groups. The first bee visitors appeared after the partial opening of flowers (5:30 a.m.). All buds from each inflorescence opened in a interval of six or seven days, and the number of open flowers per day $(n=10$ inflorescences) indicated that two flowering peaks occurred on the fourth and sixth days, with an average of 161.1 and 50.7 flowers, respectively (Fig. 2). The breeding system tests indicate that Davilla kunthii is self-compatible, and data from cross and pollinator-driven natural pollination were very similar ( $\chi 2$ : 0.5843, p: 0.4446; Tab. 1$)$.

We collected 771 bee visitors harvesting pollen, divided into 35 species (Tab. 2). The species accumulation curve did not reach total saturation (Fig. 3), although it is believed that species important for the pollination of D. kunthii have been captured. Bee species found in all four sample groups are presented in Table 1. A Diptera (Syrphidae) was also observed feeding on pollen, which, due to its harvesting behaviour, may be considered a pollinator. Moreover, two species of Vespidae were observed consuming pollen, and one species of Curculionidae was observed walking on the flowers and laying eggs on them. The body surface of the Curculionidae was covered with pollen grains. However they hardly migrated between plants. This probably prevents them from being effective pollinators, yet they may serve as occasional pollinators. Categorisation of constancy revealed the absence of constant species (W). Accessory species (Y) were: Tetragona essequiboensis (sample group C), Camargoia camargoi (sample group B), Trigona group fuscipennis (sample group D) and Augochloropsis sp.3 and Plebeia sp. (sample group A). The other species were classified as rare $(\mathrm{Z})$.

Many bee species occurred in only one sampling site, as can be seen in Figure 4, which shows shared and exclusive bee visitors. Variance analysis showed a significant effect $(\mathrm{p}<0.01)$ of foraging intensity in relation to time (hours), but isolated effects in site (sample group) or the interaction of both factors were not seen ( $p>0.05$ for both). The time of highest foraging activity was in the interval between 7:00 and 10:00 a.m. (Tab. 3 and Fig. 5).

Comparing the abundance and distribution of pollinator species within individual sample groups, it is noted that even though Te. essequiboensis and Tr. gr. fuscipennis were the most abundant, they did not appear in all sample groups. Although Trigona branneri, Ca. camargoi, Cephalotrigona femorata, Melipona fulva and Melipona amazonica were of lower abundance, they were better distributed within the sample groups, as seen in the interaction web (Fig. 4). We noted dominance behaviour and intense harvesting by $T$. branneri and T. essequiboensis, with the former behaving agonistically against Apis mellifera. This behaviour was also seen in Augochloropsis sp.3, which attacked Frieseomelitta trichocerata, in this case, the latter bee flew away. Similarly, $C a$. camargoi presented aggressive behaviour towards $M$. 

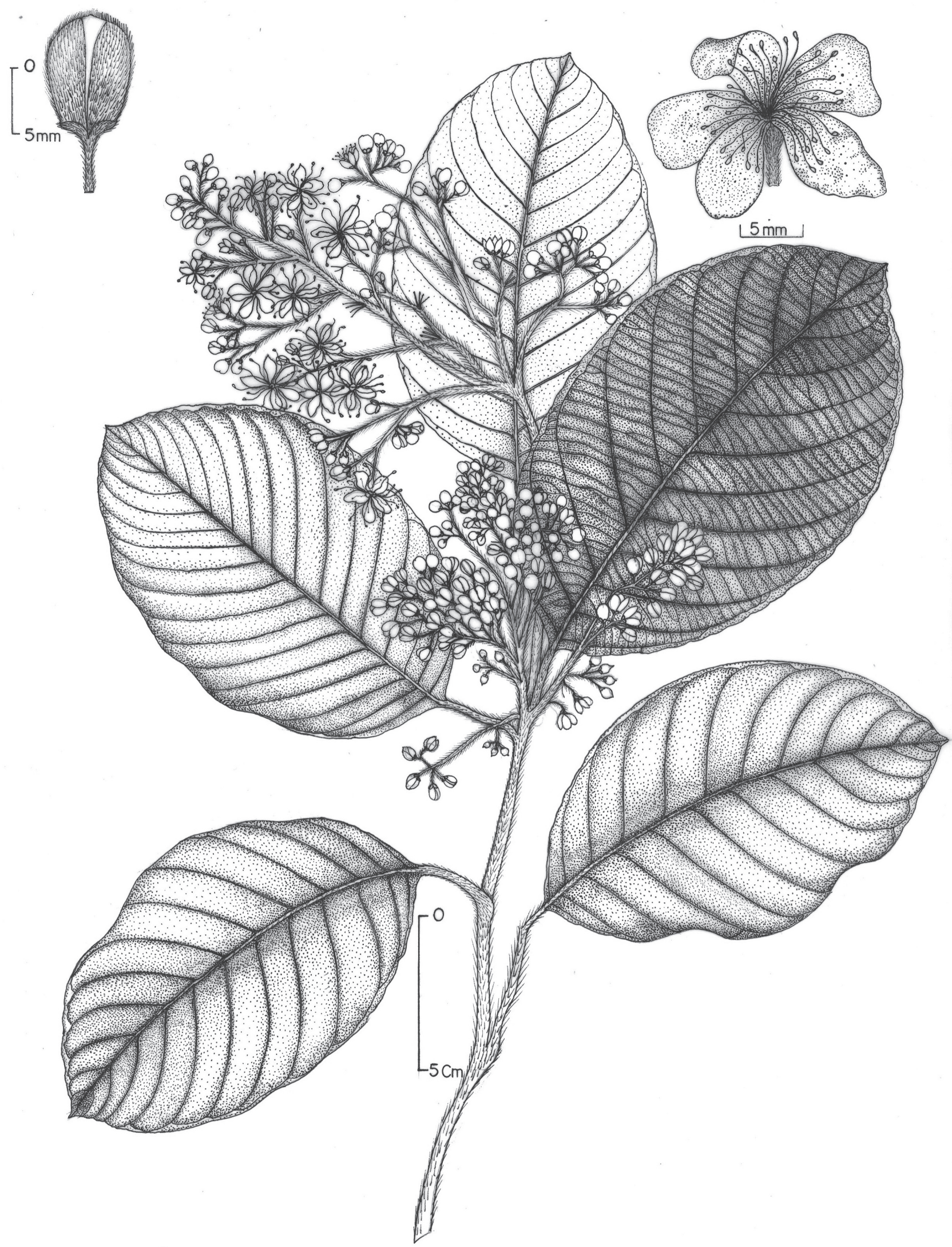

Figure 1. Illustration of Davilla kunthii A. St.-Hil., in detail the floral bud and the open flower. 


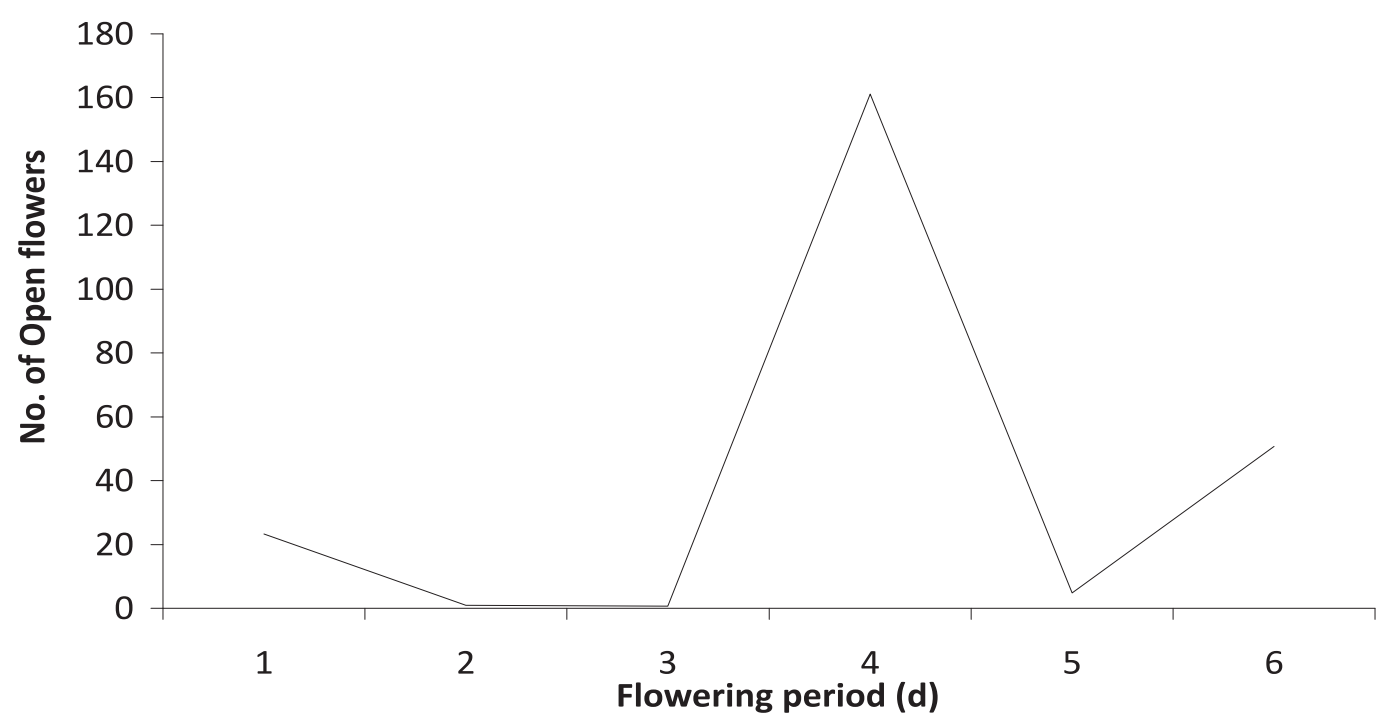

Figure 2. Flowering rhythm representing the average number of open flowers per day ( $\mathrm{n}=10$ inflorescences) in Davilla kunthii, Itacoatiara-Amazonas.

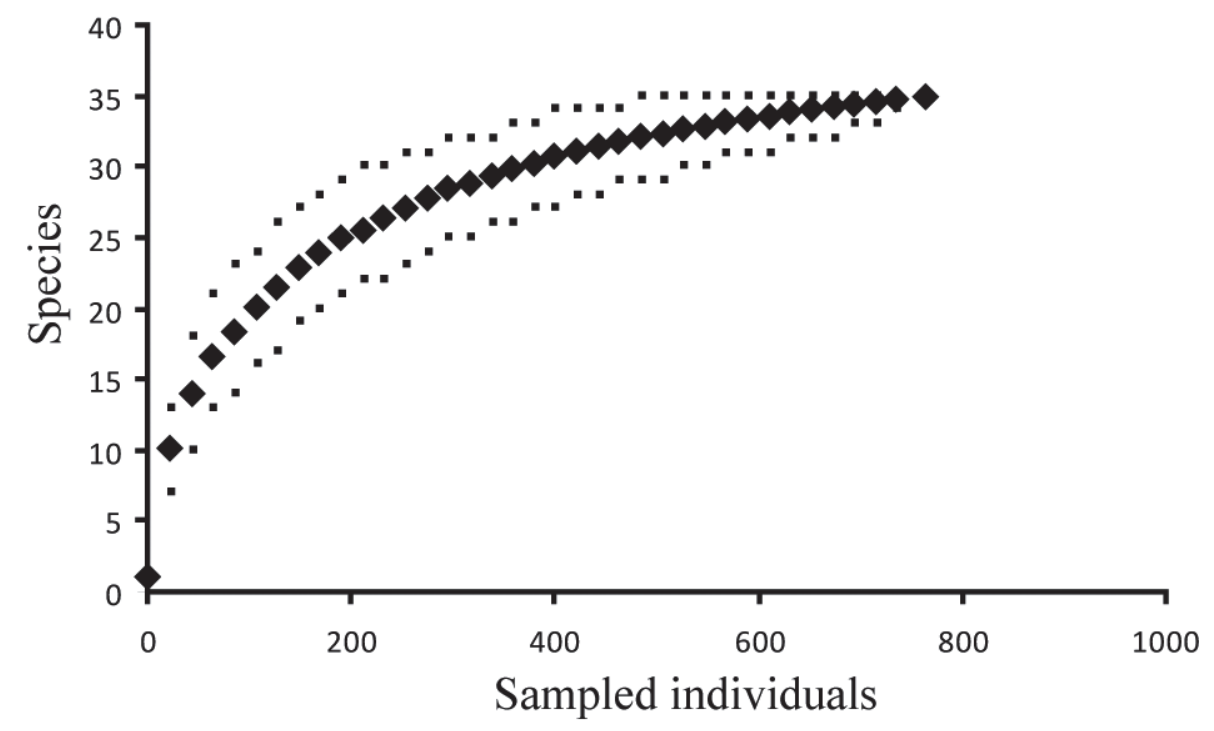

Figure 3. Collector's curve; number of individuals trapped on the X-axis and cumulative species richness on the Y-axis. Points above and below the curve indicate the confidence interval (95\% probability).

Table 1. Result of the breeding system tests indicating that Davilla kunthii is possibly self-incompatible. Natural pollination refers to pollination made by floral visitors.

\begin{tabular}{lccc}
\hline Treatment & Flower Tested & Results & Percentage \\
\hline Self-pollination & 337 & 0 & 0 \\
Spontaneous self-pollination & 1633 & 3 & 0,18 \\
Geitonogamy & 296 & 18 & 6,08 \\
Xenogamy & 298 & 86 & 28,85 \\
Agamospermy & 77 & 0 & 0 \\
Natural pollination & 524 & 166 & 31,67 \\
\hline
\end{tabular}




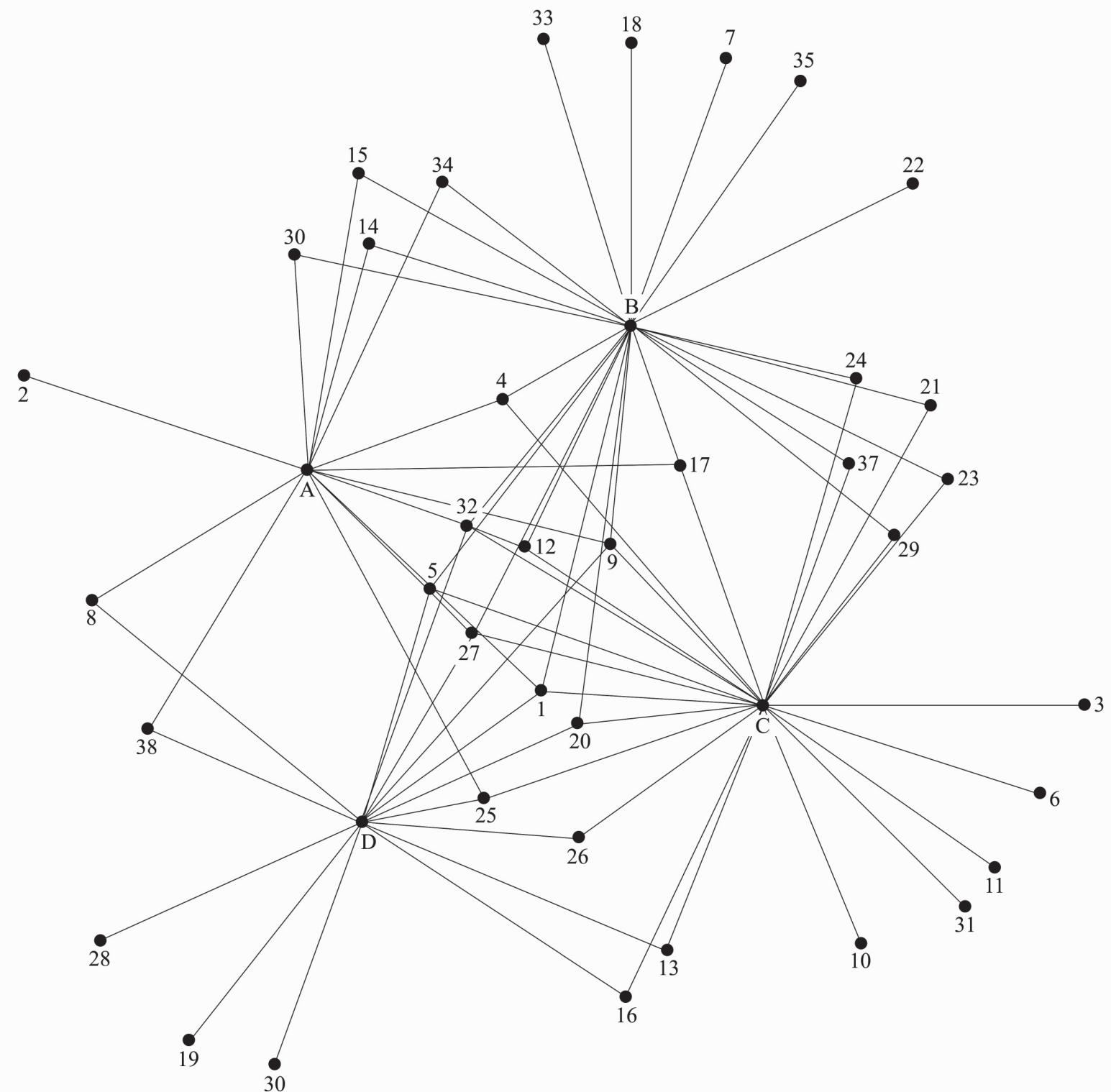

Figure 4. Interaction web representing relations between bee species and sample groups of Davilla kunthii, bee numbers refer to Table 2.

amazonica and also against smaller bees, chasing them away while it harvested part of the reward (individuals group of D. kunthii) in a monopolistic way.

Early in the morning, larger bees (such as A. mellifera) harvested more intensely in the canopy extensions of $D$. kunthii, where it was not possible to collect them. These bees began to collect in lower extensions of the vines between 9:00 and 10:00 a.m., which is probably related to the decrease in the more aggressive species that are concentrated in the early morning hours. Smaller species such as Schwarzula coccidophila, Trigonisca vitrifrons, Plebeia sp. and Augochloropsis sp. 3 did not contact the stigma when walking or collecting pollen and instead walked only on the petals.

We also verified the predation of floral visitors by ants that constantly scouted the entire inflorescence in plant individuals group A and B. When bees noted the presence of ants (five to eight on each inflorescence), they tended to avoid them or fly away. One Curculionidae species, which is also predated by ants, flew in front of a senescent flower and oviposited between the stamens or near the ovary, which are subsequently covered by closing acrescent sepals. When Curculionidae larvae hatch inside the chamber of acrescent sepals, they feed on the seed and developing fruit. Of the 937 sepal chambers opened and counted, 311 had Curculionidae larvae (34\%) and $626 \mathrm{did}$ not (66\%).

\section{Discussion}

The mass-flowering pattern found in D. kunthii, which was asyncronic among sample groups and peaking during 
Table 2. Total abundance and frequency at the four plant sample group of insects captured on flowers of Davilla kunthii in Itacoatiara-AM in August 2007.

\begin{tabular}{|c|c|c|c|c|c|}
\hline \multirow{2}{*}{ Species } & \multicolumn{4}{|c|}{ Frequency $(\%)$} & \multirow{2}{*}{ Total Abundance } \\
\hline & A & B & C & $\mathrm{D}$ & \\
\hline \multicolumn{6}{|l|}{ Apidae: Apini } \\
\hline 1. Apis mellifera Linnaeus, 1758 & 2,9 & 0,74 & 2,3 & 10,9 & 22 \\
\hline \multicolumn{6}{|l|}{ Apidae: Exomalopsini } \\
\hline 2. Exomalopsis sp. & 1,7 & 0 & 0 & 0 & 3 \\
\hline \multicolumn{6}{|l|}{ Apidae: Meliponini } \\
\hline 3. Aparatrigona impunctata (Ducke, 1916) & 0 & 0 & 0,3 & 0 & 1 \\
\hline 4. Camargoia camargoi Moure, 1989 & 1,7 & 31,11 & 4,8 & 0 & 64 \\
\hline 5. Cephalotrigona cf. femorata & 0,6 & 5,19 & 6,8 & 6,3 & 39 \\
\hline 6. Frieseomelitta silvestrii Friese, 1902 & 0 & 0 & 0,3 & 0 & 1 \\
\hline 7. F. portoi (Friese, 1900) & 0 & 0,74 & 0 & 0 & 1 \\
\hline 8. F. trichocerata Moure, 1990 & 1,1 & 0 & 0 & 1,6 & 3 \\
\hline 9. Melipona amazonica Schulz, 1905 & 0,6 & 1,48 & 0,8 & 1,6 & 7 \\
\hline 10. M. bradleyi Schwarz, 1932 & 0 & 0 & 0,5 & 0 & 2 \\
\hline 11. M. captiosa Moure, 1962 & 0 & 0 & 0,8 & 0 & 3 \\
\hline 12. M. fulva Lepeletier, 1836 & 0,6 & 0,74 & 1,5 & 9,4 & 14 \\
\hline 13. M. lateralis Erichson, 1848 & 0 & 0 & 0,5 & 1,6 & 3 \\
\hline 14. Nannotrigona sp. & 2,9 & 0,74 & 0 & 0 & 6 \\
\hline 15. Partamona mourei Camargo, 1980 & 1,1 & 3,7 & 0 & 0 & 7 \\
\hline 16. P. vicina Camargo, 1980 & 0 & 0 & 1,8 & 6,3 & 11 \\
\hline 17. Plebeia sp. & 30,3 & 6,67 & 0,8 & 0 & 65 \\
\hline 18. Ptilotrigona lurida (Smith, 1854) & 0 & 1,48 & 0 & 0 & 2 \\
\hline 19. Schwarzula coccidophila Camargo \& Pedro, 2002 & 0 & 0 & 0 & 1,6 & 1 \\
\hline 20. Tetragona beebei (Schwarz,1938) & 0 & 2,22 & 0,8 & 1,6 & 7 \\
\hline 21. Te. essequiboensis (Schwarz, 1940) & 0 & 16,3 & 44,8 & 0 & 200 \\
\hline 22. Te. goettei (Friese, 1900) & 0 & 2,96 & 0 & 0 & 4 \\
\hline 23. Te. handlirschii (Friese, 1900) & 0 & 4,44 & 1,0 & 0 & 10 \\
\hline 24. Tetragonisca gr. angustula & 0 & 2,22 & 2,8 & 0 & 14 \\
\hline 25. Trigona branneri Cockerell, 1912 & 14,9 & 0 & 1,8 & 21,9 & 47 \\
\hline 26. Tr. gr. fuscipennis & 0 & 0 & 24,2 & 25 & 112 \\
\hline 27. Tr. guianae Cockerell, 1910 & 1,7 & 5,93 & 2,5 & 1,6 & 22 \\
\hline 28. Tr. lacteipennis Friese, 1900 & 0 & 0 & 0 & 3,2 & 2 \\
\hline 29. Trigonisca vitrifrons Albuq. \& Camargo, 2007 & 0 & 1,48 & 0,3 & 0 & 3 \\
\hline \multicolumn{6}{|l|}{ Apidae: Tetrapediini } \\
\hline 30. Tetrapedia sp. 1 & 0 & 0 & 0 & 4,7 & 3 \\
\hline 31. Tetrapedia sp. 2 & 0 & 0 & 0,3 & 0 & 1 \\
\hline \multicolumn{6}{|l|}{ Halictidae: Augochlorini } \\
\hline 32. Augochloropsis sp. 1 & 1,1 & 0,74 & 0,5 & 1,6 & 6 \\
\hline 33. Augochloropsis sp. 2 & 0 & 3,7 & 0 & 0 & 5 \\
\hline 34. Augochloropsis sp. 3 & 37,7 & 3,7 & 0 & 0 & 71 \\
\hline \multicolumn{6}{|l|}{ Megachilidae: Megachilini } \\
\hline 35. Megachile sp. & 0 & 0,76 & 0 & 0 & 1 \\
\hline \multicolumn{6}{|l|}{ Vespidae } \\
\hline 36. Vespidae sp. 1 & 0,6 & 1,48 & 0 & 0 & 3 \\
\hline 37. Vespidae sp. 2 & 0 & 1,48 & 0,3 & 0 & 3 \\
\hline \multicolumn{6}{|l|}{ Syrphidae } \\
\hline 38. Syrphidae sp. & 0,6 & 0 & 0 & 1,6 & 2 \\
\hline Species richness & 16 & 23 & 23 & 15 & 38 \\
\hline Abundance & 173 & 131 & 396 & 63 & 771 \\
\hline
\end{tabular}




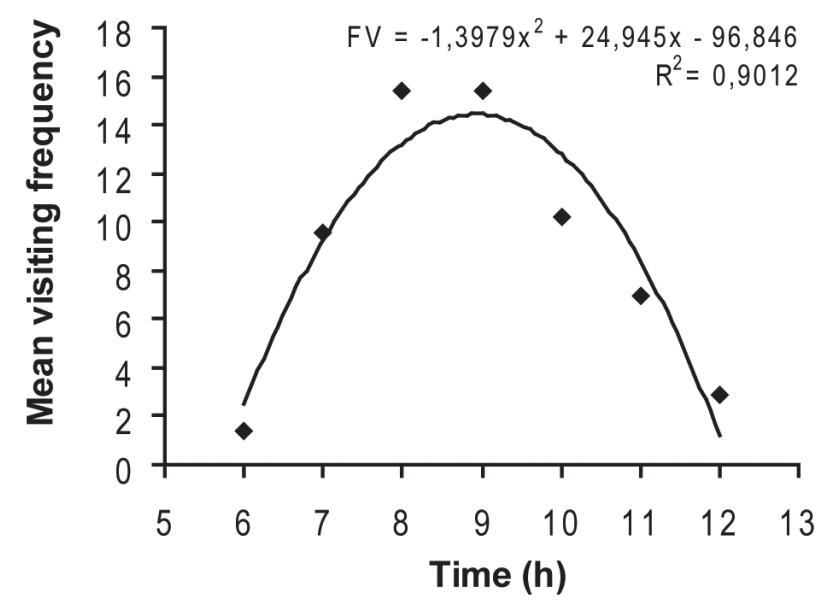

Figure 5. Mean floral visitors foraging intensity on Davilla kunthii along the assessing times (hours), Itacoatiara-Amazonas, 2007.

the flowering period, corroborates the observations for $D$. elliptica A. St-Hil. (Rocha \& Lomônaco 2006). Also in common with D. elliptica is the 6:20 h opening time (Gottsberger 1977). However, in the same study, which was conducted in Cerrado vegetation, $D$. elliptica was first visited by $A$. mellifera and later by Meliponini. Considering the high harvesting activity frequency of $A$. mellifera, we believe this behavior may interfere with the later harvest activity of Meliponini . In our study, A. mellifera visited infrequently, and the Meliponini began to harvest even before the petals opened entirely. We believe that intercalated flowering peaks among individuals (Fig. 2) is a strategy which forces bees to forage over proximally located individuals during the flowering period.

A simple flower of low restrictive morphology (plate-like), like that of Davilla kunthii, permits that different visitor species deposit a sufficient quantity of pollen grains per visit, independent of their morphological characteristics (Gómez 2002). The facility of accessing reproductive parts is even more capable of promoting fertilization in plants with few ovules (Johnson et al. 1995), like D. kunthii. Nevertheless, taking into consideration that Davilla is preferentially xenogamic, it is necessary that the visitor transports pollen among individuals. Since natural fructification (pollinator driven) was very similar to that of xenogamy, it seems visitors are acting as pollen vectors, which leads us to conclude that there is no pollen limitation in $D$. kunthii. The short period between flower anthesis and petal dehiscence is already known in Davilla spp. in the Cerrado (Gottsberger 1977). Moreover, petals fall three hours after opening, remaining open only during the highest foraging period (between 7:00 and 10:00 a.m). This leads us to think that petals perhaps serve as pollen source indicators to visitors, also evidenced by the visible decrease of pollen collected following senescence.

In the analysis of the collector's curve (Fig. 3), it should be noted that the sampling effort was not enough to reach the entire saturation of the curve. However, we feel that it is sufficient to support the fact that $D$. kunthi is generalist in a taxonomic point of view. Furthermore, we support Herrera's (2005) view that one should be focused on the visit event itself, as less frequent species have a lower importance for pollination. Hence, a much higher sampling effort would be necessary to saturate the curve, and this effort may not reveal more species that are important for the plant's reproductive success. This previous statement is based upon D. kunthii having been visited not only by 35 bee species but also by a Syrphidae, two Vespidae and a Curculionidae species.

However, from a different perspective, it is noted that all visitors, except beetles, present similar functionality, harvesting behaviour and are motivated to visit the plant by the collection of pollen, which gathers all of them into the same functional group. According to Fenster et al. (2004) and Armbruster et al. (2002), these functional groups of visitors may collectively drive the evolution of plants, so a similar process could have occurred in the case of D. kunthii. In our study, pollinators have no morphological characters substantially different to mediate any modification in the floral traits. Therefore the plant has no possibility of establishing a hierarchy of pollinators according to the differential importance of them (Schemske \& Horvitz 1984; Stanton et al. 1991; Galen 1999; Zamora 2000). In such a process flowers would be adapted to be pollinated by the "most effective group of pollinators" rather than the "most effective pollinator" species (Stebbins 1970).

The absence of constant floral visitor species in this study (according to classification of Bödenheimer 1955) may be related to the great availability of sympatric polliniferous species in the study area. An example of the latter

Table 3. Results of variance analysis for foraging intensity. We tested the local influence, time (h) and the interaction local ${ }^{\star}$ time.

\begin{tabular}{|c|c|c|c|c|c|}
\hline Variation Source & Degrees of freedom & Sum Square & Mean Square & $\mathrm{Fc}$ & $\mathrm{p}>\mathrm{Fc}$ \\
\hline Site & 3 & 49.654762 & 16.551587 & 3.339 & 0.0974 \\
\hline Error 1 & 6 & 29.738095 & 4.956349 & & \\
\hline Time & 6 & 65.071429 & 10.845238 & 12.069 & 0.0000 \\
\hline Site ${ }^{\star}$ Time & 18 & 24.928571 & 1.384921 & 1.541 & 0.1151 \\
\hline Error 2 & 50 & 44.928571 & 0.898571 & & \\
\hline Total corrected & 83 & 214.321429 & & & \\
\hline
\end{tabular}


is B. chrysophyla ("murici" with oil and pollen as reward), on whose flowers we observed bees not found visiting $D$. kunthii, but many visitors of Davilla were seen foraging on B. chrysophyla. Furthermore, several authors point out that inter-plant competition may diminish the quantity and quality of pollen deposited on co-specific stigmas, as constancy of visitors is affected (Harder \& Barret 1996; Caruso 1999; Brown et al. 2002). Working on mono-specific and mixed environments, Bell et al. (2005) found $42 \%$ plant-plant and $10 \%$ inter-specifically flower-flower movement in mixed environments, which greatly decreased the pollination efficiency at this site.

The web diagram (Fig. 4) illustrates the interactions between sample groups and visiting bees, clearly showing the shared and the exclusive bee species in the four sample groups of $D$. kunthii. The existence of unique species (visitors of only one sample group) is in agreement with the perspective that oscillations in the composition of the visiting guild depends more upon the characteristics of each species of visitor (Ramalho et a.l 1994, 1998; 2004; Herrera 1995; 1997) and especially upon agonistic interactions and the proximity of the floral source to the nesting sites of the bees (Hilário et al . 2000; 2001; Kajobe et al 2007). From our observations, we conclude that distances over $4 \mathrm{~km}$ between sample groups of $D$. kunthii explain the presence of unique species in each sample site, considering that stingless bees normally fly no more than $2 \mathrm{~km}$ (Araújo et al. 2004). Therefore the common species found in more than one sampling site probably came from different nests.

Some surveys regard beetles (Scarabeidae, Chrysomelidae and Curculionidae) as the main pollinators of Hibbertia hypericoides (DC.) Benth., H. scandens (Willd.) Gilg, and other species of Dilleniaceae, whereas bees and flies had secondary importance (Keighery 1975). Later, Bernhardt (1984) stated that flowers of $H$. stricta are visited by beetles and bees. Despite this reference to beetles, Armstrong (1979), in his review, added eight genera of Australian bees (Apidae) collected on the flowers of Hibbertia spp. and characterised these plants as bee-attractive. Recently, a review of studies on Hibbertia concluded that species within this genus are pollinated primarily by Apidae and pollen-collecting Syrphidae, claiming that bees are more efficient than beetles for pollination (Tucker \& Bernhardt 2000). Although $D$. kunthii was visited occasionally pollinated by beetles, we agree with Gottsberger (1977), who pointed out that there is a destruction of 20 to $30 \%$ of fruits in D. elliptica and up to $100 \%$ in D. rugosa. Thus, we believe that beetles have a greater impact as seed predators than as pollinators, since they are found in a large proportion of fruits (34\%). Hence, after adding our data to those of Gottsberger (1977) and Tucker and Bernhardt (2000), we come to the conclusion that bees may be the main group of pollinators of Dilleniaceae genera, although studies with other genera and more observation would be required to confirm this assertion.

\section{Acknowledgements}

We thank Dr. João Maria Franco Camargo (in memorian) for identifying bees; Dr. Antonio Carlos Webber for suggestions on the first version of this manuscript; Drs. Peter Endress, Klaus Kubitzki and Gerardo Aymard for literature and personal communications; Drs Marina Röderstein and Maria do Carmo Estanislau do Amaral for literature. We also thank Fazenda Agropecuária Aruanã and Schwade Family for infrastructure, M.Sc. Charles Fernando Silva for field work support, Dra. Yara Jardim Rosa for data analisys support, Felipe França for plant illustration and CNPq for partly funding this study (Processo 472563/2006-8).

\section{References}

Araújo, E.D.; Costa, M.; Chaud-Netto, J. \& Fowler, H.G. 2004. Body size and flight distance in stingless bees (Hymenoptera: Meliponini): inference of flight range and possible ecological implications. Brazilian Journal of Biology 64(3B): 563-568.

Armbruster, W.S. 1985. Patterns of character divergence and the evolution of reproductive acotypes of Dalechampia scandens (Euphorbiaceae). Evolution 39: 733-752.

Armbruster, W.S.; Edwards, M.E. \& Debevec, E.M. 1994. Character displacement generates assemblages structure of Western Australian triggerplants (Stylidium). Ecology 75: 315-329.

Armbruster, W.S.; Mulder, C.P.H.; Baldwin, B.G.; Kalisz, S.; Wessa, B. \& Nute, H. 2002. Comparative analysis of late floral development and mating-system evolution in tribe Collinsieae (Scrophulariaceae, s.l.). American Journal of Botany 89: 37-49.

Armelin, R.S. \& Mantovani, W. 2001. Definições de clareira natural e suas implicações no estudo da dinâmica sucessional em florestas. Rodriguesia 52(81): 5-15.

Armstrong, J.A. 1979. Biotic pollination mechanisms in the Australian flora - a review. New Zealand Journal of Botany 17: 467-508.

Bawa, K.S. 1990. Plant-pollinator interactions in tropical rain forests. Annual Review Ecological and Systematics 21: 399-422.

Bell, J.M.; Karron, J.D. \& Mitchell, R.J. 2005. Interspecific competition for pollination lowers seed production and outcrossing in Mimulus ringens. Ecology 86: 762-771.

Bernhardt, P. 1984. The pollination biology of Hibbertia stricta (Dilleniaceae). Plant Systematics and Evolution 147: 267-277.

Bodenheimer, F. S. 1955. Precis d'écologie animal. Paris, Payot.

Brown, B.J. \& Mitchell, R.J. 2001. Competition for pollination: effects of pollen of an invasive plant on seed set of a native congener. Oecologia 129: 43-49.

Brown, B.J.; Mitchell, R.J. \& Graham, S.A. 2002. Competition for pollination between an invasive species (purple loosestrife) and a native congener. Ecology 83: 2328-2336.

Camargo, J.M.F. \& Pedro, S.R.M. 2008. Meliponini Lepeletier, 1836. In: Moure, J.S, Urban, D; Melo, G A.R (Orgs). Catalogue of Bees (Hymenoptera, Apoidea) in the Neotropical Region - online version [internet]. Available from http://www.moure.cria.org.br/catalogue.

Caruso, C.M. 1999. Pollination of Ipomopsis aggregate (Polemoniaceae): effects of intra vs. interspecific competition. American Journal of Botany 86: 663-668.

Caruso, C.M. 2000. Competition for pollination influences selection on floral traits of Ipomopsis aggregate. Evolution 54: 1546-1557.

Conner, J.K. \& Neumeier, R. 1995. Effects of black mustard population size on the taxonomic composition of pollinators. Oecologia 104: 218-224.

Corbet, S.A.; Williams, I.H. \& Osborne, J.L. 1991. Bees and the pollination of crops and wild flowers in the European Community. Bee World 72(2): 47-59.

Croat, T. 1978. Flora of Barro Colorado Island. Stanford, Stanford University Press. 
Ducke, A. 1902. Beobachtungen über Blütenbesuch, Erscheinungszeit etc. der bei Para vorkommenden Bienen. II. Allgemeine Zeitschrift für Entomologie 7: 321-326, 360-368, 400-405, 417-422.

Eckhart, V.M. 1991. The effects of floral display on pollinator visitation vary among populations of Phacelia linearis (Hydrophyllaceae). Evolutionary Ecology 5: 370-384.

Fenster, C.B.; Armbruster, W.S.; Wilson, P.; Dudash, M.R. \& Thomson, J.D. 2004. Pollination syndromes and floral specialization. Annual reviews of Ecology, Evolution and Systematics 35: 375-403.

Free, J.B. 1993. Insect pollination of crops. London, Academic Press.

Galen, C. 1999. Why do flowers vary? Bioscience 49: 631-640.

Gómez, J.M. 2002. Generalización en las interacciones entre plantas y polinizadores. Revista Chilena Historia Natural. 75:1-30.

Gotelli, N.J. \& Entsminger, G.L. 2009. EcoSim: Null models software for ecology. Version 7. Acquired Intelligence Inc. \& Kesey-Bear. Jericho, VT 05465. http://garyentsminger.com/ecosim.htm

Gottsberger, G. 1977. Some aspects of beetle pollination in the evolution of flowering plants. Plant Systematics and Evolution, Supplement 1: $211-226$

Harder, L.D. \& Barrett, S.C.H. 1996. Pollen dispersal and mating patterns in animal-pollinated plants. Pp. 140-190. In: Lloyd, D.G \& Barrett S.C.H. (Eds.) Floral Biology: studies on floral evolution in animalpollinated plants. New York, Chapman and Hall.

Herrera, C.M. 1995. Microclimate and individual variation in pollinators: flowering plants are more than their flowers. Ecology 76: 1516-1524.

Herrera, C.M. 1997. Thermal biology and foraging responses of insects pollinators to the forest floor irradiance mosaic. Oikos 78: 601-611

Herrera, C.M. 2005. Plant generalization on pollinators: species property or local phenomenon? American Journal of Botany 92(1): 13-20.

Hilário, S.D.; Imperatriz-Fonseca, V.L. \& Kleinert, A.M.P. 2000. Flight activity and colony strength in the stingless bees Melipona bicolor bicolor (Apidae, Meliponinae). Revista Brasileira de Biologia 60(2): 299-306.

Hilário, S.D.; Imperatriz-Fonseca, V.L. \& Kleinert, A.M.P. 2001. Responses to climatic factors by foragers Plebeia pugnax Moure (in litt.) (Apidae, Meliponinae). Revista Brasileira de Biologia 61(2): 191-196.

Johnson, S.G.; Delph, L.F. \& Elderkin; C.L. 1995. The effect of petal-size manipulation on pollen removal, see set, and insect-visitor behavior in Campanula americana. Oecologia 102: 174-179.

Kajobe, R. 2007. Pollen foraging by Apis mellifera and stingless bees Meliponula bocandei and Meliponula nebulata in Bwindi Impenetrable National Park, Uganda. African Journal of Ecology 45(3): 265-274.

Kearns, C.A. \& Inouye, D.W. 1993. Techniques for pollination biologists. Niwot, University Press of Colorado.

Keighery, G.J. 1975. Pollination of Hibbertia hypericoides (Dilleniaceae) and its evolutionary significance. Journal of Natural History 9: 681-684.

Kuhlmann, M. \& Kühn, E. 1947. A Flora do Distrito de Ibiti. São Paulo, Secretaria da Agricultura, Instituto de Botânica, Serie Botânica.

Michener, C.D. 2000. The Bees of the World. Baltimore, John Hopkins University Press.

Nascimento, H.E.M. \& Laurance, W.F. 2006. Efeitos de área e de borda sobre a estrutura florestal em fragmentos de floresta de terra firme após 13-17 anos de isolamento. Acta Amazônica 36(2): 183-192.

Newstrom, L.F., Frankie, G.W. \& Baker, H.G. 1994. A new classification for plant phenology based on flowering patterns in lowland tropical rain forest trees at La Selva, Costa Rica. Biotropica 26: 141-159.
Nilsson, L.A. 1987. Angrecoid orchids and hawkmonths in central Madagascar: specialized pollination system and generalist foragers. Biotropica 19: 310-318.

Nilsson, L.A. 1983. Mimesis of bellflower (Campanula) by the red helleborine orchid Cephalantera rubra. Nature 305: 799-800.

Ollerton, J. 1999. La evolución de las relaciones polinizador-planta en los Artrópodos. Boletin de La Sociedad Entomológica Aragonesa (España) 26: 741-758.

Ramalho, M.; Giannini, T.C.; Malagodi-Braga, K.S. \& Imperatriz-Fonseca, V.L. 1994. Pollen harvest by stingless bee foragers (Hymenoptera, Apidae, Meliponinae). Grana 33: 239-244.

Ramalho, M.; Imperatriz-Fonseca, V.L. \& Giannini, T.C. 1998. Withincolony size variation of foragers and pollen load capacity in the stingless bee Melipona quadrifasciata anthidioides Lepeletier (Apidae, Hymenoptera). Apidologie 29: 221-228.

Ramalho, M.; Silva, M.D. \& Carvalho, A.L. 2004. Dinâmica de uso das fontes de pólen por Melipona scutellaris Latreile (Hymenoptera, Apidae): uma análise comparativa com Apis mellifera (Hymenoptera, Apidae) no domínio tropical atlântico. Neotropical Entomology 36(1): $38-45$

Rathcke, B. 1983. Competition and facilitation among plants for pollination. Pp. 305-329. In: Real, L. (Ed.) Pollination biology. Orlando, Academic Press.

Rocha, F.L.C. \& Lomônaco, C. 2006. Phenotypic variation in Davilla elliptica A. St.-Hil. (Dilleniaceae) and Byrsonima intermedia A. Juss. (Malpighiaceae) subpopulations in a savanna/"vereda" transitional area. Acta Botanica Brasilica 20(3): 719-725.

Roll, J.; Mitchell, R.J.; Cabin, R.J. \& Marshall, D.L. 1997. Reproductive success increase with local density of conspecific in a desert mustard (Lesquerella fendleri). L 11: 738-746.

Roubik, D.W. 1989. Ecology and natural history of tropical bees. Cambrige, University Press.

Schemske, D.W. \& Horvitz, C.C. 1984. Variation among floral visitors in pollination ability: a precondition for mutualism specialization. Science 225: 519-521.

Schemske, D.W. 1981. Floral convergence and pollinator sharing in two bee-pollinated tropical herbs. Ecology 62: 946-954.

Sih, A. \& Baltus, M. 1987. Patch size, pollinator behavior, and pollinator limitation in catnip. Ecology 68: 1679-1690.

Stanton, M.; Young, H.J.; Ellstrand, N.C. \& Clegg, J.M. 1991. Consequences of floral variation for male and female reproduction in experimental populations of wild radish, Raphanus sativus L. Evolution 45: 268-280.

Stebbins, G.L. 1970. Adaptive Radiation of Reproductive Characteristics in Angiosperms, I: Pollination Mechanisms. Annual Review of Ecology and Systematics 1: 307-326.

Stone, G.; Willmer, P.G. \& Rowe, J.A. 1998. Partitioning of pollinators during flowering in an African Acacia community. Ecology 79: 2808-2827.

Temeles, E.J. \& Kress, W.J. 2003. Adaptation in a plant-hummingbird association. Science 300: 630-633.

Tucker, S.C. \& Bernhardt, P. 2000. Floral ontogeny, pattern formation, and evolution in Hibbertia and Adrastaea (Dilleniaceae). American Journal of Botany 87: 1915-1936.

Waser, N.M. 1983. Competition for pollination and floral character differences among sympatric plant species: a review of evidence. Pp. 277-293. In: Jones, C.E. \& Little, R.J. (Ed.). Handbook of experimental pollination biology. New York, Van Nostrand Reinhold New York.

Zamora, R. 2000. Functional equivalence in plant-animal interactions: ecological and evolutionary consequences. Oikos 88: 442-447. 